\title{
The Nature of the Principle of Deterrence in the Nuclear Actions of the Islamic Republic of Iran
}

\author{
Sarmadi $\mathrm{H}^{1 *}$, Ismailzadeh $\mathbf{M}^{2}$, Karimi J ${ }^{3}$ and Hassanpour $\mathbf{E}^{3}$ \\ ${ }^{1} \mathrm{PhD}$ in Political Science, Lecturer of Islamic Azad University, Iran \\ ${ }^{2}$ Master candidate of International Relations, Islamic Azad University, Iran \\ ${ }^{3}$ M.A of International Relations, Islamic Azad University, Iran
}

*Corresponding author: Hamid Sarmadi, PhD in Political Science, Lecturer of Islamic Azad University, Islamic Azad University, Bonab Branch, Bonab, Iran, Email: hamedsarmadi2000@ gmail.com

\section{Review Article \\ Volume 4 Issue 1}

Received Date: February 18, 2021

Published Date: March 09, 2021

DOI: $10.23880 /$ abca-16000164

\section{Abstract}

US foreign policy during the Obama administration, especially in the second term, has focused to resolve its international crises in the Middle East and tried to resolve the Iranian nuclear issue. In the current article, different approaches are brought forth in the field of discerning deterrence mechanisms that are feasible against asymmetric hazards. In the following, the attempts has been made to answer the question of how deterrence can be utilized as a mechanism to face asymmetric threats, and what role can Iran's nuclear program play in deterring countries in power in this process?. Hence, from the analysis of the mentioned model, we will present the main and major assumptions of the current article under four headings: deterrent measures, coercive measures, anti-deployment measures and counter-offensive measures. The tensions between Iran and the West are not the product of Iran's nuclear program, but are based on the religious ideology of the Iranian government and Israel's presence in the region, although the role of some Arab countries, especially Saudi Arabia, should not be disregarded. The hypothesis under consideration is that US foreign policy in the Iranian nuclear case has been directed towards the interaction of national interests by following the rational, organizational and bureaucratic model of decision-making models. The result of the research is that think tanks are very determining in leading the US government to the White House foreign policy decision-maker towards Iran, so that diplomacy actors cannot escape it. And public opinion seeks to make Iran's nuclear energy dangerous and to prevent Iran from obtaining a nuclear weapon as a serious threat to humanity. Though, the Islamic Republic of Iran, with its power to obtain nuclear weapons, does not intend to build a nuclear bomb, nor does it intend to make the world insecure. The power of reaching to a nuclear weapon can play a key and major role for Iran as a deterrent, and Iran intends to use nuclear energy not to build a bomb but to make it peaceful.

Keywords: Asymmetric Threats; Deterrence Principle; Borjam Agreement; Pressure; Satirical Risk; Wet Strategies; Counterattack and Leverage

\section{Introduction and Problem Statement}

In status que, the existing literature in the fields of strategy and defense places incredible emphasis on the concept of asymmetric warfare. This has been taken into the account not only in developed countries, but also in developing and underdeveloped countries. The events of 11 of September, 2001 , concluded to the emergence of new forms of threats on the international scene. Therefore, the Middle East region is not far from the scope of these new threats and under the 
influence of the hegemonic indicators of the United States of America, regional crises have increased widely. Therefore, in such an atmosphere, the security concerns of regional actors, especially Iran, have increased to some extent, and naturally, each of the political units in the region is trying to improve its position. Therefore, in such a situation, the adoption of some strategies, especially the pursuit of an appropriate defense strategy for the security of the Islamic Republic of Iran in the face of asymmetric threats in the form of the principle of deterrence becomes concrete. In this regard, paragraph 24 of the document of political, economic and cultural development programs emphasizes on enhancing the defense capability of the armed forces to protect the vital resources of the country and the Islamic Revolution and the basis of the country's defense strategy defines the act of deterrence. It is stated in this paragraph that effective confrontation against threats and protection of national interests and the Islamic Revolution and vital resources of the country is important, but accurate and precise evaluation of the elements of dealing with asymmetric threats, subject to more accurate analysis of the main parameters of the mechanism. In the process of evaluating this model, it seems necessary to examine and explain the realism approach, because deterrence is based on ideas about systems of threats and commitments subject to the imposition of punishment, which is particularly consistent with the branch of strategic studies in the realist tradition. Thus, deterrence is a special case of power relations.

Realists locate their principles on knowledge and individualism and are not agree with imaginative predictions. Accentuating the issue of security, they hold that if a government fails to maintain its security, it will not be able to do anything. Under such conditions, an efficient military force is essential to support diplomacy, foreign policy, and ultimately security [1]. Realist analysts believe that the foreign policy of countries interacts in an environment that lacks central supremacy, not in the sense that there is disorder, but in the sense that there is no authority or superiority to establish legal rules and procedures. Confirms the inherent sovereignty of countries.

In the framework of this approach in the international system, every country should think about itself based on the principle of self-help and there is no higher power to support them. Therefore, every political unit should seek to empower and produce its own power [2]. Therefore, taking into account the above-mentioned issues, preserving the country's territorial integrity, defending the country against foreign aggression, maintaining the ability to deal with military and security threats of other actors and creating a stable environment to ensure national interests and spread Islamic values are the most important goals of defense strategy is the Islamic Republic of Iran. In addition, in line with the goal of empowering the country, we must emphasize the strengthening of technological, practical and research strength in the military-economic dimension, so that we can increase our political influence in the region and expand our security borders [2].

Therefore, significant elements of the deterrence strategy include intense and fierce arms competition, which is equipped with the most modern weapons and technology weapons. Naturally, in this vein, having a strong diplomatic staff to implement the deterrence strategy along with the arms race is an important tool for the deterrent country. In fact, the deterrent country must be constantly active in the arms race and increasingly seek to acquire the most advanced military technology and superiority of arms over others. Given that the Islamic Republic of Iran is facing a wide wave of threats, especially asymmetric threats, which itself has a very complex process, so the definition of asymmetric threat in the next article seems vital. The most important feature of international politics is the effort and power struggle between the units that want to change and distribute power and the units that want to maintain the status quo. The need for a balance of power and the need for normative mechanisms to pacify the system are features of the world order. According to Morgenthau, the balance of power system is not only inevitable but also a stabilizing factor in international relations [3].

The balance of power is a modern and rational theory that can be explained in a liberal context as it can be explained from the perspective of realism. In Grossiusi's view; International balance is not a crude military balance. Rather, it represents the approximate equality of the capabilities of large countries, so that none of them can dominate the others [4]. The most effective deterrent strategy is one that prevents the formation of threats and displays credible threats. Basically, in regional deterrence, the question must be answered how to validate one's threats to the other side or the enemy.

Part of the answer to this question lies in past actions or encounters. Behaviors and responses in previous conflicts and crises show the seriousness of making declared threats and carrying out alleged actions [5]. In this regard, and based on various parameters, including the type of tools and strategic games, as well as the parties involved, the most important forms of regional deterrence can be expressed as follows:

- Nuclear deterrence

- Conventional deterrence

- Unilateral and Extensive Deterrence

- Indirect Deterrence

- Direct and Reciprocal Deterrence

- Network Deterrence [5]. 
Classical regional deterrence requires the use of two types of defense and offensive tools, each of which focuses on target points. On the other hand, each country has vulnerabilities as well as opportunities that can affect the type of deterrent methods. The choice of deterrence strategy is directly related to the theory of defense and attack. According to this theory, defense-aggression and the type of equation between them will lead countries to adopt one of them. In other words, the ease of defense and the difficulty of the attack lead to the choice of defense strategy and vice versa, the adoption of an offensive strategy. The regional deterrence system as one of the teams that is responsible for ensuring the order of the region is strongly influenced by the variables that form the above equation Ghasemi, et al. [5].

At the end of World War II, the world model became based on a bipolar system, some of which converted to the Eastern bloc and some to the Western bloc. Meanwhile, the Islamic Republic of Iran and Saudi Arabia were able to establish relative stability in the region before the victory of the Islamic Revolution, according to the US two-pillar policy as the axis of the Middle East geopolitical balance with the support of the US Navy, but after the victory of the Islamic Revolution and its withdrawal. The geopolitical structure of the West and the collapse of the Santo Pact and the emergence of geopolitical events in the region, Iran-Saudi relations until the end of the 1360s tended to conflicts. But after the adoption of UN Resolution 598 by the Islamic Republic of Iran and the end of the Iran-Iraq war, the Iraqi invasion of Kuwait, the collapse of the Soviet Union, Iran moved away from confrontation with the Persian Gulf countries and tended to adopt expedient and peaceful methods. These relations continued until the 2001s, but after the second decade of 2001 due to the US policy towards Saudi Arabia, Saudi domestic developments, the death of King Abdullah, Iran's foreign policy, Saudi Arabia's tense regional policy, developments in the Arab world, civil wars. In Syria, Yemen, etc., it became dark [2].

Now, with the nuclear agreement between Iran and the Western countries on the one hand and Iran's influential role in regional crises such as Syria, Iraq, and Yemen on the other hand, the grounds for increasing the regional power of Iran and Shiites in the region have been prepared. This has intensified regional rivalry between Iran and Saudi Arabia. The most important areas of differences between Iran and Saudi Arabia can be explored in multiple dimensions of security, political, identity, economic and ideological. Reduce Iran's geopolitics and relative power in the region [6].

\section{Asymmetric Threats}

The term asymmetric threats have been used since the 1990 s to cover a wide range of unconventional threats. At first glance, asymmetry means taking advantage of some kind of difference that leads to overcoming the enemy. Asymmetric threats are defined in different ways, while such threats are seen in all reports, documents and writings along with asymmetric warfare [7].

Asymmetric warfare means thinking, organizing, and conducting operations different from what the enemy is doing, in order to maximize one's strengths or exploit the enemy's weaknesses. Asymmetric intimidators try to target the weak points of the enemy, with a small number of forces and with a strategy of war without conflict or using suicide operations and conducting remote operations, strike at the strong enemy. Asymmetric threats are relative and some are more asymmetric. What these threats to threats Asymmetric conversion is the difference in the concepts of the operation and that such threats are used against the enemy's unexpected vulnerabilities. In this case, the country that is targeted is usually surprised and this breaking state may delay the reaction of the other party [7].

In general, the main elements of asymmetric threats are the use of innovative and creative methods, exploiting the vulnerable points of the enemy, using advanced technologies, weakening the will of the superior enemy and emphasizing disproportionate effects.

Considering the above, the significant point in discussing threats is that threats are not fixed, but change regularly and based on the requirements and developments of time, environment and the extent of its perception and identification. Therefore, defense strategies using deterrence strategy will necessarily deal with a combination of military, political, diplomatic, and economic and intelligence power with the other side [7].

Therefore, it seems that utilizing unique capabilities and innovative tactics can create the appropriate countermeasures in line with the deterrence strategy. Also, the use of anti-access measures can make a desirable deterrent possible and prevent the entry of American forces into the security zone of Iran or slow down their movement [7]. The principle of nuclear deterrence In an interview with NBC, the Iranian foreign minister stressed that Iran is stronger, more advanced and more successful than its neighbors and does not need nuclear weapons.

Iran is taking all necessary steps to convince the world that Iran is not seeking nuclear weapons. "We are committed to everything that assures the international community that we are not seeking nuclear weapons," Zarif said in an interview because we are not looking for nuclear weapons. We see no interest in nuclear proliferation. Iran's foreign minister in response to the host of the program who said for what benefit you do not see in having nuclear weapons; 
Because you are a Shiite country and the Sunni countries that are not good to you are surrounded by you, he replied that these are all miscalculations that a Shiite country is seeking to develop nuclear weapons to protect itself from its Sunni neighbors. "Geopolitics - the fact that we have grown up, the fact that our human resources are much more advanced than our neighbors all of this gives us inherent strengths that we do not need to strengthen our capabilities anymore." The foreign minister called the principle of nuclear deterrence "insane" and said that Pakistan, because it has nuclear weapons, It is not considered stronger than Iran. There is a fact that everyone in the international community believes that the definitive reciprocal destruction is complete insanity. This is the way in which the United States, Russia and others seek peace and security through the possibility of destroying each other Ahmadi M, et al. [8].

Diplomatic apparatus urgent and deterrent measures against the United States. The National Security and Foreign Policy Commission monitors international developments and monitors US actions to abuse paragraphs 11 and 12 of Resolution 2231 and the Comprehensive Joint Action Plan (CJAP) and seeks to activate the trigger mechanism and reverse UN Security Council resolutions against our country, Announces:

1. According to international standards, the United States, by withdrawing from the second appendix of the resolution and not fulfilling its obligations to the Iranian nation, does not have the legitimacy to use the dispute resolution mechanism in Articles 36 and 37 of the UN Security Council. The legal interpretation provided by the United States is baseless and unjustified.

2. The Islamic Republic of Iran expects the member states of the UN Security Council to prevent the abuse of the United States in order to counter US unilateralism and to maintain the validity of international rules, and to prevent the arbitrary behavior of the US government to impose its will on other countries.

3. It is expected that the diplomatic apparatus of the Islamic Republic of Iran, following the brave and revolutionary nation of our country, will take urgent and deterrent measures against the United States by using the available capacities, as well as its obvious abuse of the Security Council and disclose the veto.

4. In case of illegal activation of the trigger mechanism, the Atomic Energy Organization should immediately return all nuclear activity to the level before 1994, using IR4, IR6, IR8 generation centrifuges to meet the country's needs to supply 190,000 tons Enrichment, take action. Also, to accelerate the construction of nuclear propellants in order to equip our country's navy.

5. The National Security and Foreign Policy Commission of the Islamic Consultative Assembly are ready to prepare and approve the necessary laws and approvals in case the United States pursues illegal and extravagant actions.

6. Accompanying European countries with the hostile and arbitrary actions of the United States, while damaging the prestige of these countries, will weaken their interests, and Iran advises to refrain from accompanying this action of the Americans.

7. The members of the Islamic Consultative Assembly adhere to their pact with the nation in order to protect national interests and by monitoring international and regional developments, their duties in pursuing issues within the framework of the constitution and the measures of the wise leader of the revolution based on the three principles of dignity, wisdom and expediency Follow Najafi, et al. [9].

The position of the elite in the political approach of the United States of America, due to the increasing complexity in international equations and calculations, the importance of expert forces in explaining matters and determining the best ways to play a role in the global system has increased. Under such circumstances, political elites in research and study centers in many countries have found a favorable environment to participate in the formal decision-making process in the field of foreign policy. Elites in many developed countries, especially the United States, have a direct or indirect influence on foreign policy. The tangible costs and benefits of accepting their proposals and the priority set for a particular political issue can determine the degree of influence of political elites on the adoption of political approaches. In general, the ways in which think tanks influence the process [5].

\section{US Elite Approach to Iran's Nuclear Case}

The elites play an influential role in directing US foreign and security policy by conceptualizing, scenario-building, and mentally nurturing the centers of power. Observations of study plans, annual reports, and comments by senior US think tank researchers indicate four approaches to Iran. Control of Iran's nuclear power by using soft power and consequently paying the lowest cost Dr. Sarjan Thomson, a leading BritishAmerican Council researcher and former British ambassador to India and High Representative to the United Nations, in the final report of the Iran Nuclear Case Study Project sent to the White House in March 2007, despite emphasizing control over Iran's nuclear capability. This underscores that there are many different ways to control Iran's nuclear program, but the important point is that many of these ways come at a heavy cost to the United States. He states that the best way to control Iran's nuclear capability is to persuade Iran to negotiate and open a dialogue with this country, in which 


\section{Annals of Bioethics \& Clinical Applications}

case the US government will achieve the best result at the lowest cost [5].

\section{Achieving Great Success and Restoring American Prestige}

Outcome Yves Dalder, Miklo Michael Laviaz Leading researchers at the Brookings Institution think tank in their investigation into the Iranian nuclear issue have spoken of the need for US cooperation with the European Union in dealing with Iran; The threats posed by Iran are aimed more at Europe than at the United States, so the United States must work with Europe to resolve this issue. He blamed military action on Iran for intensifying the country's need to increase its weapons security, and said that if the US government succeeded in resolving Iran's nuclear issue peacefully, it would undermine US prestige. It restores the unilateral foreign policy of this country and the failure in Iraq and Afghanistan [10].

\section{The Approach of Pushing from Within (inside)}

Another approach taken by some prominent American institutions and personalities is the approach of internal pressure or public dissatisfaction with the Iranian government's nuclear policies. One of the most prominent theorists of this approach is Richard Armitage, the former US Deputy Secretary of State and one of the leading figures of the so-called State Department in the United States. Armitage and his colleagues at State Department research institutes believe that the Iranian government considers nuclear technology to be a central component of national security and is accepted as a belief that every day injects to the context of the Society. Emphasizing the influence of the masses' beliefs on government policy, Armitage puts forward the idea that the US government should do its utmost to neutralize the Iranian government's nuclear energy propaganda so that the nuclear case, its domestic support, to lose in Iran. In this way, the Iranian government is forced to comply with the demands of Europe and the United States.

Armitage's strategy for realizing this blueprint is to launch internal discussions about the risks of acquiring nuclear technology and Iran's enrichment efforts.

He believes that by launching these discussions, the Iranian government is trying to express the feelings and ignorance of the people, to feel the flow and to use national feelings. Armitage further mentions scientific awareness using domestic pro-Western intellectuals and foreign tools such as media such as VOA, Radio Farda, etc. as a tool to neutralize the actions of the Iranian government [10].

\section{Using the Maximum Capacity of Bar Jam}

The Comprehensive Joint Action Plan (CJAP), which was agreed between the Islamic Republic of Iran and the P5 +1 countries in July 2015, was approved by the Supreme National Security Council, the Islamic Consultative Assembly, and finally the Supreme Leader on December 17, 2015. This was despite the fact that the provisions of this program were approved despite all the sharp differences between the two major parties of the United States of America (Democratic and Republican) over the text of this agreement. Now that it has been in place since its inception, the page of international politics has changed. On the one hand, contrary to expectations and public predictions, Republican candidate Donald Trump, in a special contest, was able to rely on 306 electoral votes to be elected the next president of the United States and from the beginning of 2017, the helm of leadership Take over this country. This issue is important because he is one of the main critics of Borjam and has repeatedly stated that if he wins the US presidential election and enters the White House, he will tear Borjam apart and wants to talk again to formulate another joint program. . Of course, how much Trump can fulfill this political promise. It is worth pondering. According to most international experts and policymakers, including EU foreign policy chief Federica Mogherini and coordinator of the Joint Commission; The nuclear deal was adopted in the form of Security Council Resolution 2231 and is not a bilateral or unilateral issue, but a multilateral one, and therefore US President Donald Trump cannot unilaterally violate the nuclear deal. In addition, in accordance with the obligations set forth in the Bar Jam, the President of the United States is committed to implementing the provisions of the UNHCR and must use his powers to prevent any action contrary to the Bar Jam. Many US political experts, including White House spokesman Josh Ernst, also believe that there is a tradition of agreements and contracts being signed by the US executive that future presidents retain some elements of continuity in those agreements.

It should not be overlooked that even assuming the withdrawal of the United States from the IAEA, while Iran can use past experiences in a short time to reach pre-Bar Jam conditions in the nuclear industry; Creating a global consensus against Iran is a very difficult task; Because it is not Iran that has violated the constitution, but the United States did so. And this is definitely not acceptable from the point of view of the international community. In fact, Burjam has become a global demand. At the same time, however, the implementation of the IAEA Board has imposed restrictions on Iran in the nuclear industry on the one hand, and on the other hand in discussing the obstacles to the lifting of sanctions, as intended, the sanctions are practical, especially in the area of The big banks and insurance companies have not been removed, but Borjam has given the Iranian economy 
an opportunity to use the space created, while releasing the blocked Iranian money in other countries, to attract foreign investment in the fields of oil and gas, petrochemicals, transportation industry and Transport, shipping and to be facilitated $[11,12]$.

\section{Conclusion}

Reviewing and evaluating policy-making groups and circles in US policies toward Iran can make a significant contribution to a more accurate understanding of policies. US unilateral sanctions have been imposed on Iran. The role of Israeli lobbies and American political elites is to properly identify and manage ways to exert power. By recruiting, communicating or inviting agents close to the centers of power, they are used as a bridge between decision-making or decision-making centers, which can be well done in the case of sanctions against Iran observed. Iran has three options regarding its nuclear program: first, to abandon its entire nuclear program, second, to continue the current negotiation cycle, and third, to withdraw from this cycle and acquire a nuclear weapon. The first option is neither realistic nor advisable. The abandonment of the nuclear program will not only not solve Iran's security problem, but will also redouble security concerns for Iranian decision-makers and elites. The second option also has no clear vision. An unresolved cycle that is about two decades old and not only does not seem to solve the problem of survival, but also exacerbates it. Especially since there is no consensus in the country on it. The final option for Iran is nuclear deterrence. The most important result of this research has been that, no matter what Europeans think about their strategic interests, it does not include nuclear deterrence. This mindset did not change after Barack Obama introduced the strategy of turning to Asia. And now that Donald Trump has left the UN Security Council, he continues to see Iran's nuclear program as dangerous, and despite the fact that the Iranian government speaks of the peaceful nature of its nuclear program, the US government and the P $5+1$ still pose a threat to Humanity introduces that while Iran does not have such an approach, but these countries do not even accept Iran's nuclear program as a deterrent, while they themselves are constantly inciting war in countries with military and political weakness. In addition, they have used nuclear weapons in the past and are themselves a threat to the world, but they are resisting Iran for having nuclear energy if Iran does not make a decision, but the P $5+1$ countries do not want Iran to be able to have deterrence and not to use peaceful nuclear energy.

Mr. Biden also announced his country's return to the Borjam agreement before winning the US election, but given Biden's background and US foreign policy, one cannot expect to meet all of the commitments made in Borjam, as Biden himself is a politician. Which demands maximum pressure on Iran and the return of the United States to Borjam can be considered a new weapon to control Iran. The Islamic Republic of Iran needs a defense capability to be able to withstand threats from the United States and other countries, but that deterrence capability does not have to be a nuclear bomb. The P $5+1$ group knows Iran well, but in order to put maximum pressure on Iran and deceive the public mind, they emphasize on Iran's construction and use of the nuclear bomb in order to achieve their political goals.

Today, all countries of the world need deterrent power, but upsetting the balance of power is not in the interest of the international community. Iran also does not seek to build or use a nuclear bomb, but to deter and prevent threats from other countries, it needs to prevent the principle of deterrence to prevent the authoritarianism of countries with military power and advance its goals.

In other words, whether the US strategy in this defensive action as it claims or offensive what Iran and some countries perceive is a threat to the security of the country and the strategy that is taken against it. "Reciprocal strategy is the principle of deterrence."

\section{References}

1. Hossein S (2005) Principles and models of decision making in foreign policy, Tehran: Ministry of Foreign Affairs Publications.

2. Khani A, Vakardan A (2011) American approaches and plans about Iran, Tehran: Abrar Moaser.

3. Sheihan, Michael (2017) International Security. $2^{\text {nd }}$ (Edn.), Research Institute for Strategic Studies Publications.

4. Asadi, Abbas (2016) Political History of the Egyptian Press. $1^{\text {st }}$ (Edn.), Tehran: Avae Noor Publications.

5. Ghasemi, Farhad (2015) Theories of International Relations and Regional Studies, Tehran, Mizan Publishing.

6. Darabi, Vahid, Kazemi, Hamed (2016) The Crisis of Confrontation and Balance of Power in the Foreign Policy of Iran and Saudi Arabia. Journal of Nations Research 2(15).

7. Naghibzadeh, Ahmad (2006) Decision Making Process in Iranian Foreign Policy, Tehran: Strategic Research Center. Journal of Iranian Nuclear Program.

8. Ahmadi M, Hossein (2015) The Challenge of Turkey's Strategic Alliance with Saudi Arabia, Research Institute for Strategic Studies in the Middle East. 


\section{Annals of Bioethics \& Clinical Applications}

9. Najafi, Mostafa (1396) Siege of Iran and Israel in the Gray Zone of Russia. IRAS, pp: 2.

10. Jomehzadeh I, Javad S, Babaei, Mojtaba (2015) US Foreign Affairs on Iran's Nuclear Case. Journal of International Relations 8(29).
11. Ghavam, Abdolali S (2015) Transformation in Theories and Approaches. 10 $0^{\text {th }}$ (Edn.), Organization for the Study and Compilation of University Humanities Books.

12. Reza M (2005) Expert Report on Analysis and Evaluation of US Research Centers' Approach to Iran's Nuclear Case, Islamic Consultative Assembly Research Center.

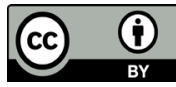

